\title{
The Shintoization of the Chinese Sea Goddess in Early Modern Japan
}

\author{
Wai-ming ng
}

\begin{abstract}
The Chinese sea goddess Mazu (Maso in Japanese) became a popular folk religion in early modern Japan (1603 -1868) when Mazu was worshiped in different parts of Japan from northern Honshu to Kyushu and the Ryukyu Kingdom. This study examines the localization of Mazu in Tokugawa Japan, using Mito and Satsuma as the main references. The Mazu belief in these two domains was differ ent from the country of its origin in terms of names, festival dates, forms of worship, and temple design. Mazu was incorporated into the Shino framework, transformed into Shinto deity bearing the title of daigongen (Great Avatar) or daimyojin (Great Illuminator Deity) and worshiped in Shinto style. Mazu was either enshrined or associated with other Shinto deities. Based on Tokugawa texts, this paper looks into how Mazu was included in the Shinto framework and identified with such Shinto deities as Ototachibanahime, Noma gongen and Funadama. It aims to deepen our understanding of the nature of Sino-Japanese cultural interchange in the early modern period.
\end{abstract}

